\title{
PRESUPPOSITION ANALYSIS IN SOME SELECTED CONSUMER ADVERTISEMENT SLOGANS OF THE JAKARTA POST
}

\author{
Sinta Ananda \\ Department of English Education, University of Kuningan, Indonesia \\ Email: ananda.sinta15@gmail.com \\ Marwito Wihadi \\ Department of English Education, University of Kuningan, Indonesia \\ Email: m_wihadi@yahoo.com \\ Yayan Suryana \\ Department of English Education, University of Kuningan, Indonesia \\ Email: ysuryana2008@gmail.com
}

\begin{abstract}
APA Citation: Ananda, S., Wihadi, M., \& Suryana, Y. (2016). Presupposition analysis in some selected consumer advertisement slogans of the Jakarta Post. English Review: Journal of English Education, 5(1), 141-148
\end{abstract}

\begin{abstract}
This research investigates the presupposition in the slogans of consumer advertisement of the Jakarta Post newspaper on March 2016 edition. This research aimed at finding the types of presupposition and describing the functions of presupposition in advertisement found in consumer advertisement slogans of the Jakarta post newspaper. Yule's theory and descriptive qualitative research method applied in this research. 20 slogans of consumer advertisement of the Jakarta Post newspaper on March 2016 edition selected to this research. The result of this research showed that the writer found 20 presuppositions. 11 existential presupposition or $55 \%$, 4 factive presupposition or $20 \%$, 3 lexical presupposition or $15 \%$, and 2 non-factual presupposition or $10 \%$. Regarding the function of presupposition in advertisement, the writer found 17 slogans advertisement contains implicit competition, and 11 slogans advertisement contains making the advertisement short and memorable. In conclusion, not all type of presupposition and function of presupposition in advertisement are found, it is influenced by various types and functions in advertisement causing different assumption and presupposition. The writer hopes that further researchers who are interested in observing presupposition to explore more about presupposition in other types of advertisement.
\end{abstract}

Keywords: presupposition, consumer, advertisement, slogan

\section{INTRODUCTION}

This research investigates the presupposition in the slogans of consumer advertisement of the Jakarta Post newspaper. The writer wants to make an interesting research by choosing the data source from slogans of advertisement, because advertising slogan is one of manifestations of language use in human social life particularly through media.

In daily activities, sometimes people are looking for and need some information from the advertisement, whether it is to fill of spare time or perhaps has become a necessity. The 
advertisement can be found almost everywhere, such as newspaper, magazine, television, radio, etc. The advertisement is one of ways used by the advertisers to convey information, with purpose to introduce and to promote their products or services to consumers. In other words, the advertisement is inescapable parts of modern life that can influence others.

The readers need advertisement when they want to see or to buy something, which usually accompanied by picture and slogan form. Indirectly, the slogan purposes to offer the potential product and service to consumers. "The slogan is intended to motivate the potential consumer of the goods or services" (Batyrovna, 2014, p. 262). However, when conveying the message through slogan, the readers do not realize that what is behind the slogan in the advertisement has a meaning, function even type that can attract public attention. They do not realize that behind an advertisement, all the advertisers are competing to make an advertisement with display or interesting language use in order to make the consumers interested in buying the products or the services advertised. The success of the advertisers in marketing products cannot be separated from how the advertisers promote the products. "The advertisers should know who their customers are, what media is used, what message that would appeal to them, and how to get their attention" (Griffin \& Ebert, 2007, p. 368). To attract the consumers' attentions, language has an important role in advertising. Through language, the message of the advertisers can be delivered and can be accepted by the consumers. To achieve these objectives, the advertisers promote their products by using persuasive language. Griffin and Ebert (2007) states that persuasive language in advertising is a strategy of advertising influence consumers to purchase a particular product. Persuasive language is used to persuade others who become the advertisement target to be interested toward the products or the services advertised.

When the advertisers will convey information through the advertisement, previously, the advertisers make the beginning assumption or inference of what will be delivered. It is purpose in order to the readers can understand the intent of the advertisers. The assumption or inference above on pragmatic study is called presuppositions.

The advertisers implement pragmatic approach in communicating purpose to persuade the readers use or purchase the products advertised. "Presupposition is something the speaker assumes to be the case prior to making an utterance" (Yule, 1996, p. 25). It means that how people can describe their process of thinking in analyzing implicit meaning, and how listeners or readers can catch other information beyond their interpretation.

In this research, the writer tries to find out the types of presupposition and describe the functions of presupposition in advertisement are found in the slogans of consumer advertisement of the Jakarta Post newspaper. The writer thinks that the types and the functions of presupposition in advertisement slogans are important to be understood deeply.

\section{METHOD}

The research method which used in this research is descriptive qualitative method. Fraenkel, Wallen and Hyun (2012, p. 427) states that "Qualitative data are collected in the form of words or pictures rather than numbers." This 
research is classified as descriptive qualitative method since the data in the form of words, utterances, pictures rather than numbers. As Yin (2011) states that qualitative research involves defining something to investigate, collect the relevant data, analyze and interpret the result, and draw a conclusion. It means that descriptive qualitative is a method of research involving method of collecting, classifying, interpreting, describing, and drawing conclusion.

\section{Data Source}

In this research, the writer took the data from the Jakarta Post newspaper during a month. The data were all consumer advertisements in the Jakarta Post newspaper on March, $1^{\text {st }} 31^{\text {st }} 2016$ editions. The writer selected 20 data slogans of consumer advertisement from the Jakarta Post newspaper on March 2016 edition. The writer chose the Jakarta Post newspaper because it was one of a daily English Newspaper in Indonesia.

\section{Technique of Collecting Data}

Technique of collecting data is the way of writer to collect and to get the data. There are some steps to collect the data. First of all, the writer collected the Jakarta Post newspaper containing of consumer advertisements. Then, the writer identified one by one the consumer advertisements containing slogan. After identifying the consumer advertisement slogans, the writer selected the consumer advertisement slogans containing presupposition. Next, the writer scanned the pictures of selected consumer advertisement in order to make the readers see the pictures of advertisement slogan easily and clearly.

\section{Technique of Analyzing Data}

Technique of analyzing data is the way of writer to analyze and to get the result. There are some steps to analyze the data. First step, the writer read one by one selected slogans of consumer advertisement from the Jakarta Post newspaper on March 2016 edition. Second step, the writer classified the data based on the types and the functions of presupposition in advertisement. Third step, after classifying the types and the functions of presupposition, the writer interpreted the types of presupposition from each slogan in the advertisement. Fourth step, the writer counted the occurrence from each type of presupposition and converted the occurrences into percentage. In determining the result of the types of presupposition in form of percentage, the writer used the formula based on the theory from Subana (as cited in Oktoma \& Mardiyono, 2013, p. 79), as follow:

$$
\text { FK rel }=\frac{F K}{\sum F} \times 100 \%
$$

FK rel in this formula means frequency of relative cumulative (the result of percentage), FK means frequency of cumulative (the number of the occurrences of certain type of presupposition), means frequency of total (the number of the whole occurrences of presupposition) and 100\% means percentage.

Fifth step, the writer gave pictures of consumer advertisement in every classification the types and the functions of presupposition. Then, the writer described the types and the functions of presupposition from each slogan in advertisement. The last step, the writer drew a conclusion from the analysis. 


\section{RESULTS AND DISCUSSION}

Yule (1996) divides

presupposition into six types. They are existential presupposition, factive presupposition, lexical presupposition, structural presupposition, non-factive presupposition and counter-factual presupposition.
In this research, the writer found 70 consumer advertisements in the Jakarta Post newspaper on March, $1^{\text {st- } 31^{\text {st }}}$ 2016 editions, and selected 20 data slogans of consumer advertisements.

The result of the type of presupposition in the consumer advertisement slogan is shown in the form of table below.

Table 1. The Result of the Types of Presupposition

\begin{tabular}{ccc}
\hline Types of presupposition & Frequency & Percentage \\
\hline Existential & 11 & $55 \%$ \\
\hline Factive & 4 & $20 \%$ \\
\hline Lexical & 3 & $15 \%$ \\
\hline Non-factive & 2 & $10 \%$ \\
\hline Total & 20 & $100 \%$ \\
\hline
\end{tabular}

(Yule, 1996)

The result of analysis above, the writer found 20 presuppositions and only found four types of presupposition in the slogans of consumer advertisement of the Jakarta Post newspaper on March, $1^{\text {st-31st }} 2016$ editions. Four types of presupposition are 11 existential presupposition or $55 \%, 4$ factive presupposition or $20 \%$, 3 lexical presupposition or $15 \%$, and 2 non-factive presupposition or $10 \%$.

In conclusion, existential presupposition is type of presupposition often used by the advertisers to convey their products or service to consumers. The advertisers often use the type of existential presupposition in delivering the product or the service. Probably, the advertisers assume that the type of existential presupposition more easy to promote the product or the service advertised, compared with other types of presupposition. The advertisers use some exaggerated words, phrases and expressions to describe and to achieve sales promotion of products and services advertised. Existential presupposition is one of types of presupposition the exaggeration in delivering information. However, if the information transmitted through presuppositions, the exaggeration properties it will facilitate in promoting the products (Yingfang, 2007).

Meanwhile, the writer did not find structural presupposition and counter-factual presupposition as listed in Yule's theory. The advertisers do not use structural presupposition and counter-factual presupposition. Probably, the advertisers fear if the readers have assumption of contrary to facts stated in the advertisement and also difficult to state inserted information. So it will becomes ambiguous and cause mistrust of the consumers towards the advertisers. Yule (1996) states that counterfactual presupposition is the opposite of what is true or contrary to fact. Structural presupposition is obtained from the sentence structure of "wh-question" followed state contains inserted information.

Regarding the process of analyzing the function of presupposition in the slogans of consumer 
advertisement, the writer used Lam's discussion about the functions of presupposition in advertisement. Lam (2009) divides the functions of presupposition into three functions. They are implicit competition, causing reader to consider the existence of product and service, and making the advertisement short and memorable.

The result of the function of presupposition in advertisement is shown in the form of table below.

Table 2. The Result of the Function of Presupposition in Advertisement

\begin{tabular}{|c|c|c|c|c|}
\hline No. & Slogans & $\begin{array}{c}\text { Implicit } \\
\text { competition }\end{array}$ & $\begin{array}{c}\text { Causing readers to } \\
\text { consider the existence } \\
\text { of the products or } \\
\text { services }\end{array}$ & $\begin{array}{l}\text { Making the } \\
\text { advertisement short } \\
\text { and memorable }\end{array}$ \\
\hline 1. & The best or nothing & $\sqrt{ }$ & & $\sqrt{ }$ \\
\hline 2. & $\begin{array}{l}\text { Convenience, a luxury few can } \\
\text { enjoy }\end{array}$ & $\sqrt{ }$ & & \\
\hline 3. & Wide coverage, fast, and stable & $\sqrt{ }$ & & \\
\hline 4. & Mix it up! & & & $\sqrt{ }$ \\
\hline 5. & The essence of infinite innovation & $\sqrt{ }$ & & \\
\hline 6. & When you expect the very best & $\sqrt{ }$ & & \\
\hline 7. & Gastronomy and art & & & $\sqrt{ }$ \\
\hline 8. & Ready unit \& fully furnished & $\sqrt{ }$ & & \\
\hline 9. & The ultimate sport utility truck & $\sqrt{ }$ & & \\
\hline 10. & The total living environment & $\sqrt{ }$ & & \\
\hline 11. & Let's get together! & $\sqrt{ }$ & & $\sqrt{ }$ \\
\hline 12. & Incredible India & $\sqrt{ }$ & & $\sqrt{ }$ \\
\hline 13. & Going places together & $\sqrt{ }$ & & $\sqrt{ }$ \\
\hline 14. & Smooth as silk & $\sqrt{ }$ & & $\sqrt{ }$ \\
\hline 15. & Unlimited aesthetics & $\sqrt{ }$ & & $\sqrt{ }$ \\
\hline 16. & Wish you were here & $\sqrt{ }$ & & \\
\hline 17. & Art in your hand & $\sqrt{ }$ & & $\sqrt{ }$ \\
\hline 18. & Imagine your Korea & & & $\sqrt{ }$ \\
\hline 19. & The mainstay true business & $\sqrt{ }$ & & \\
\hline 20. & Moving service & $\sqrt{ }$ & & $\sqrt{ }$ \\
\hline & Total & 17 & 0 & 11 \\
\hline
\end{tabular}

The result of analysis above, the writers only found two functions of presupposition in advertisement. Two functions are implicit competition and making the advertisement short and memorable. 17 slogans advertisement containing implicit competition and 11 slogans advertisement containing making the advertisement short and memorable.

In conclusion, implicit competition is the function often used by the advertisers in the slogans of consumer advertisement of the Jakarta
Post newspaper on March 2016 edition. Probably, the advertisers assume that implicit competition is an easy and optimal function in delivering the message of advertisement clearly to compare the advantages of a product. Lam (2009) states that the advertisement message has to be delivered clearly but implicitly, and often used for the ease of delivering message. One of strategy in advertising is comparing two or more products directly, it purpose to steal sales from competitors (Griffin \& Ebert, 1996/2007). 
In addition, there are some slogans of consumer advertisement of the Jakarta Post newspaper on March 2016 edition has more than one function presupposition in advertisement, such as the function of implicit competition and making the advertisement short and memorable. Implicit competition and making the advertisement short and memorable are the functions which often used by the advertisers to make the language of advertising is important. Persuasive advertisement, comparative, short but memorable are needed to make the language of advertising is more important (Lam, 2009).

However, the writer did not find the function of presupposition causing the readers to consider the existence of the products or services. The advertisers do not use it function because probably the advertisers assume that it will make the readers confuse to consider existence the object advertised. So it will affect toward marketing and revenue the advertisers.

The research about using of presuppositions as a research topic a lot of conducted by researchers, with different objects and media. When reading references about presupposition, many researchers talk about type and meaning of presupposition. Therefore, the writer is interested in researching the types and the functions of presupposition in consumer advertisement slogans of the Jakarta Post newspaper. The writer uses some previous studies as references in this research. For examples of previous studies from Bonyadi and Samuel (2011), Lam (2009), Zare, Abbaspour and Nia (2012), Kurniawan (2014), Puspitasari (2015). From the results of several research above, the writer finds that the result of some research are different and similar with the result of research conducted by the writer.

The research is conducted by Bonyadi and Moses (2011) focuses on comparison toward the using of types of presupposition used in two different newspaper, America newspaper and Persian English newspaper. One of purposes from this research is to find out the types of presupposition with use Yule's theory and qualitative method. Non-factive presupposition is the type of presupposition which often used in both of newspaper, America newspaper and Persian English newspaper. This research has different result with the research is conducted by the writer. Probably, the difference happens because different object as well as the use of language to certain purpose and certain circumstance.

People speak or writer uses language with a certain purpose and in a certain circumstance. Some advertisements are designed to all readers, but some to a set of readers. Therefore, the advertiser designed advertisement for the people who intend to read them. (Yingfang, 2007, p. 59).

In other side, the research is conducted by Kurniawan (2014) has similar result with the result of research conducted by the writer. This research focuses on the types of presupposition in the slogan of outdoor advertisement. Yule's theory and descriptive qualitative method are applied in this research. The type of presupposition which often found in this research is existential presupposition. It has similar result. Probably, it happens because the writer analyzes the type of similar object, consumer advertisement. In conclusion, consumer advertisement focuses on type of existential presupposition because it refers to existence of product and service or contains referential expressions. 
"Existential presupposition is associated with referential expressions, arises simply because of an assumption that a person who uses such an expression intends to refer to something. All referential expressions give rise to existential presuppositions" (Hashim, 2014, p. 58).

Meanwhile, the discussion about the types and the function of presupposition in advertisement based on Lam's discussion is same with the discussion conducted by Puspitasari (2015) but different research object. The result of her research shows that non-factive presupposition is the type of presupposition which often used in mobile phone brochure. Implicit competition and making the advertisement short and memorable are the functions of frequently used in mobile phone. Lam (2009) states that persuasive advertisement, comparative, short and memorable are needed to make the language of advertising is important.

\section{CONCLUSION}

The research investigates the presupposition in consumer advertisement slogans of the Jakarta Post newspaper on March, $1^{\text {st }} 31^{\text {st }} 2016$ editions. This research focuses on identifying the types and the functions of presupposition in advertisement. Yule's theory and Lam's discussion are used in this research.

In the process of collecting data, the writer finds 70 consumer advertisements and selects 20 consumer advertisements containing slogans and presuppositions. From 20 slogans of consumer advertisement, the writer finds 20 presupposition and four types of presupposition in the Jakarta Post newspaper on March 2016 edition. There are 11 slogans containing existential presupposition or $55 \%$, 4 slogans containing factive presupposition or $20 \%$, 3 slogans containing lexical presupposition or $15 \%$, and 2 slogans containing nonfactive presupposition or $10 \%$. The dominant type of presupposition found in the selected consumer advertisement slogans of the Jakarta Post newspaper on March 2016 edition is existential presupposition. However, two other types of presupposition such as structural presupposition and counter-factual presupposition are not found by the writer.

Meanwhile, in the function of presupposition in advertisement, the writer only finds two functions are implicit competition and making the advertisement short and memorable. There are 17 slogans advertisement containing implicit competition and 11 slogans advertisement containing making the advertisement short and memorable. Implicit competition is the function which frequently used in consumer advertisement slogan. Meanwhile, the writer does not find the function of presupposition that cause the reader to consider the existence the product or service.

In conclusion, not all type of presupposition and function of presupposition in advertisement are found in the slogans of consumer advertisement of the Jakarta Post newspaper on March 2016 edition. It happens because the advertisers make various types and functions of advertisement in the Jakarta Post newspaper. It affects the advertisers to have different assumption about what they want delivered, and allow the advertisers to have different presupposition. The advertisers make the advertisement in Jakarta Post newspaper focuses on consumer advertisement showing the existence and the advantages of products or services. It 
is influenced by consumer needs and sales target which purpose to achieve sales promotion of products and services advertised.

\section{REFERENCES.}

Batyrovna, B,A. (2014). Semantic and pragmatic presuppositions in advertising slogans. Life Science Journal, 11(4), 261-263. Retrieved from http:/ / www.lifesciencesite.com

Bonyadi, A., \& Samuel, M. (2011). Linguistic nature of presupposition in American and Persian newspaper editorials. International Journal of Linguistics, 3(1), 1-15. Retrieved from http://www.macrothink.org/ journal/index.php/ijl/article/viewFil e/55 4/pdf

Fraenkel, J. R., Wallen, N. E., \& Hyun, H. A. (2012). How to design and evaluate research in education (8 $8^{\text {th }}$ ed.). New York, NY: The MCGraw-Hill Companies, Inc.

Griffin, R. W., \& Ebert, R. J. (2007). Bisnis: Edisi kedelapan (S. Wardhani, Trans.). Jakarta, Indonesia: Erlangga. (Original work published 1996).

Hashim, S. S. M. (2009). Existential presupposition in religious Islamic text: pragmatic implicature. International Conference on Arts, Economics and Management, 57-61. Retrieved from http://icehm.org/upload/5289ED03 14011.pdf

Kurniawan, R. (2014). An analysis of presupposition in selected slogan of outdoor advertisements. University of Kuningan: Unpublished.

Lam, K, Y, C. (2009). What is useful about presupposition in advertisements and what does it reflect?: A sociolinguistic study of Hong Kong culture, LCOM Papers, 2009(2), 45-55. Retrieved from http://www.english.hku. hk/LCOM \%20paper/LCOM\%20papers\%20new,
\% 20rev/2009\%20vol2/ 4Carr ieLam. pdf

Oktoma, E., \& Mardiyono, S. (2013). The analysis of presupposition in the short stories of Silvester Goridus Sukur. English Review: Journal of English Education, 2(1), 76-86.

Puspitasari, N. (2015). Presuppositions in mobile phone advertisements (Masters thesis, State Islamic University of Sunan Ampel, Surabaya). Retrieved from http://digilib.uinsby.ac.id/2976/

The University of Sydney Library. (2014). Your guide to APA $6^{\text {th }}$ style referencing (K. Masters, Rev.). Retrieved, from https://www.library.usyd.edu.au/su bjects/download s/citation/APA\% 20Complete 2012.pdf

Universal College of Learning. (2011). A beginner's guide to the APA referencing style (6 $6^{\text {th }}$ ed.). Retrieved from https://repository.wi.edu.au/alfresco /d/d/ workspace/S pacesStore/b9ea99d1-7b374f7cb909e5d8e413632c/ APA\% 20Referencing\%20Guide 6th\%20Edition2012.pdf

Yin, R. K. (2011). Qualitative research from start to finish. New York, NY: The Guilford.

Yingfang, W. (2007). Analysis of presupposition and its function in advertisement. Canadian Social Science, 3(4), 55-60. Retrieved from http://www.cscanada.net/inde x.php/css/article/view/j.css.19236697 2007030 4.012/438.

Yule, G. (1996). Pragmatics. Oxford, England: Oxford University Press.

Zare, J., Abbaspour, E., \& Nia, R. M. (2012). Presupposition trigger-a comparative analysis of broadcast news discourse. International Journal of Linguistics, 4(3), 734-743. Retrieved from http://www.macrothink.org/ journal/index.php /ijl/article/view / 2002/pdf 